\title{
TEACHER AND STUDENTS' PERCEPTIONS OF READING A GRAPHIC NOVEL USING THE MULTILITERACIES APPROACH IN AN ESL CLASSROOM
}

\author{
${ }^{1}$ Shahida Pishol \& ${ }^{2}$ Sarjit Kaur \\ ${ }^{1} \& 2$ School of Humanities \\ Universiti Sains Malaysia \\ ${ }^{1}$ Corresponding author: kixzz_86@yahoo.com
}

\begin{abstract}
Purpose-This article reports on the practical application of Learning Elements advocated by the multiliteracies approach to classroom practice. Its ideas are grounded in the multiliteracies pedagogical principles of teaching and learning that address issues on literacy and learning in today's globalised world. The main objective of this study was to analyse the perceptions of one ESL teacher and 24 students in reading a graphic novel using the multiliteracies approach in an ESL classroom.
\end{abstract}

Methodology - The study involved the collection of qualitative data which was derived from focus group interviews and a journal writing activity. These instruments aimed to get feedback from the ESL teacher and students about their perceptions of reading a graphic novel using the multiliteracies approach in the reading classroom. The materials used for the focus group interviews and the journal writing activity. The data from the focus group interviews were analysed by using thematic analysis. Meanwhile, the data from the teacher journal entries were subjected to a micro analysis approach using the content analysis method.

Findings - The findings showed that the students perceived the use of the graphic novel and the multiliteracies approach in their reading class positively because they felt that the lessons were engaging, enjoyable and interesting. This supported the views of the ESL teacher who advocated the inclusion of multimodal pedagogical practices in the learning context to promote positive outcomes. 
Significance - This study would benefit ESL students in terms of enjoyment in reading. Firstly, reading a graphic novel can tap into students' interest and can motivate them to read and write. Additionally, it would also motivate students to learn collaboratively with their peers. The findings of the study offer ESL teachers and researchers valuable insights of reading a graphic novel using the multiliteracies approach in reading classrooms, as well as planning effective lessons and integrating technology, in an effort to motivate students to read in English.

Keywords: multiliteracies approach; multimodal pedagogical practices; information and communication technologies; reading a graphic novel.

\section{INTRODUCTION}

Many reading lessons in Malaysian English as a Second Language (ESL hereafter) classrooms seem to be lacking in terms of enjoyment. It is seen as an increasing concern by policy makers, educators, researchers and the media in the country and needs serious attention. Due to this matter, many ESL secondary school students in Malaysia are uninterested to read English materials and this has been documented in several local studies (Pandian, 2000; Noorliza Abu Bakar, 2006; Mariyatunnitha Shari, 2011; Mohd Nazri Latiff Azmi, 2013). This problem is a setback for Malaysian students due to our exam-oriented educational system. Pedagogical practices in Malaysian schools are based on conventional methods of teaching and literacy practice as they are more teacher-centered, adopt an exam-oriented approach, place emphasis on memorisation and put excessive pressure to score good grades in exams, hence producing students who are more passive in class (Tan \& Yudi Samyudia, 2009; Mohd Nazri Latiff Azmi, 2013).

Since our lives are being inundated by Information and Communication Technologies (ICT hereafter) in the literacy field, there is a need for a paradigm shift from traditional methods to effective approaches to promote reading among students. Current changes in teaching and learning using a range of technologies seem to offer an opportunity for educators and teachers to do 
new things in new ways. It is vital for ESL teachers to integrate technology and appropriate materials to make reading lessons more enjoyable for students. In fact, reading a graphic novel by using the multiliteracies approach is worth considering in the classroom as this can help students to be active and informed citizens in future societies (Pandian \& Balraj, 2010). The graphic novel and the use of the multiliteracies approach have the potential to motivate readers as it helps students build their visual literacy, and at the same time, make reading fun (Ruppel, 2006; Heffernan, 2008). It is widely cited that the graphic novel is now commonly used in various reading lessons globally (Templer, 2009; Monnin, 2009; Faezal Muniran \& Md Ridzal Md Yusof, 2008).

This paper puts forth the argument that there is a need to take a closer look at using the multiliteracies approach in reading a graphic novel within an electronic and digital environment. The present study investigates teacher and students' perceptions in reading a graphic novel using the multiliteracies approach in an ESL classroom.

\section{THE DEVELOPMENT OF THE GRAPHIC NOVEL}

The history of the graphic novel is very much related to the history of comics. Comics have been around since the 1940s when serials of comic strips were put together into a comic book. These books are intended to reach younger readers. Therefore, most comic books describe super heroes and the plot line was developed based on action and adventure plot lines (Callahan, 2009).

In the present day, the graphic novel as a reading genre is extremely popular in various places, such as libraries and bookstores, and it has been critically analysed by various newspapers and internet sites. While in the past, graphic novels centered more on superheroes, now they have been created to place more emphasis on issues that cover various subjects (Callahan, 2009; Hoover, 2012). In recent developments, more movies are being adapted from graphic novels and comics, such as 'Superman' and 'Batman' (Ruppel, 2006). In the Malaysian context, Lat is a pioneer in this genre, especially 
in Southeast Asia. He writes stories about a traditional Malaysian village in the 1950s. It has been well received throughout Malaysia and has been adapted into the popular animated series 'Kampung Boy' (Templer, 2009).

There are various views and opinions on the graphic novel since it was first introduced. As mentioned by Yang (2008), the graphic novel is a political term as it is an effort to turn the comic medium in a new light as a literary work apart from the genre that is usually associated with it. People usually associate the graphic novel with not "real" books. This has made some educators and teachers reluctant to spend time on these nontraditional texts compared to more accepted books (Callahan, 2009). This view was also echoed by Heffernan (2008) as she also resisted using the graphic novel at first. However, her perceptions changed as she felt that graphic novels provide entertaining and creative ways to motivate students to read and write with purpose. Another scholar also mentions that graphic novels/comics were once condemned based on the following four factors (Groensteen, 2000:34):

1. they are a hybrid form combining words and images

2. the literary aspect of comics is seen as sub-par in terms of quality;

3. comics are perceived as closely connected to the "low" art of caricature;

4. comics are associated with a regression to childhood pleasures Ironically, the features that have been regarded as low standard form turned out to be the advantage of the graphic novel which has made it popular now among teachers and students (Williams, 2008).

In the teaching context, the major reason that may contribute to the resistance to use graphic novels in the classroom is that many people perceive graphic novels as being too violent and dangerous especially to young readers (Callahan, 2009). Similar to other forms of literature, not all graphic novels are suitable for particular age groups because of inappropriate content (Heffernan, 2008). In view of this, the graphic novel should be screened by the teacher before allowing students to read it (Schwarz, 2006). 
In the teaching and learning process, the teacher who can use the graphic novel competently in his/her classroom must able to present opportunities to the students to understand the texts through multiple levels (Williams, 2008; Hoover, 2012). The levels that can be considered include investigating the writers' intention, characters and setting as well as the relationship between the words and images (Williams, 2008). In order to accomplish these tasks, the students simultaneously activate their analytical skill, understanding, inference and higher order thinking skill (Smetana, Odelson, Burns \& Grisham, 2009; Hoover, 2012).

Other than that, some English teachers may use the graphic novel to teach literary aspects. They can utilise terms and techniques like dialogue as a tool to connect with other works especially from classics (Schwarz, 2002). They may use it together with the multiliteracies approach as more graphic novels have been adapted into film (Ruppel, 2006). The latest strategy that a teacher may use in teaching the graphic novel is by using the 'comic life programme' (Dony, 2009). He states that this application can be downloaded from the website which allows students to create the graphic novels with students' pictures. It offers various comic layouts and designs. The interface is also user friendly as they offer simple steps to make the graphic novel. In order to integrate the multiliteracies approach in the lesson, teachers need to explain to the students how to use the programme before the students are given the opportunity to explore it further.

The use of graphic novels in the Malaysian context bring tremendous advantages in terms of learning English, especially for second language learners. It can help lessen their anxiety and worries of learning a second language as the process of meaning making is much easier with the help of graphics. Graphic novels are also able to provide authentic discourse as readers can experience real conversations and practice the nuances of English language.

A recent study conducted by Hines and Dellinger (2011) attempted to discover whether the graphic novel has an impact on children's motivation in reading the text. In this study, Hines worked with a fifth grade group which comprised three boys and two girls from Mountain View Elementary School in Hickory, North Carolina. Meanwhile, Dellinger worked with a group of seventh graders which 
consisted of three boys and two girls at Lincolnton Middle School in Lincoln County. The researchers found that, over four weeks, nine out of ten participants improved their attitude towards reading. The findings of the study showed that many students discovered that reading could be fun and entertaining. In the Malaysian context, Melor Md Yunus et al. (2012) explored the perceptions of teacher trainees in using digital comics to teach ESL writing. The study administered a survey to 20 TESL teacher trainees from Universiti Kebangsaan Malaysia. The findings showed that most of the teacher trainees have positive perceptions of using ICT and digital comics in teaching ESL writing. They also reported that the digital comics motivated the students to write more frequently in their English lessons.

\section{THE MULTILITERACIES THEORY: CONCEPT AND APPLICATIONS}

Given the current impact of change on literacy and literate practices, it is appropriate to consider the emerging concept of multiliteracies. The term 'multiliteracies' was formulated by the New London Group (1996) based on the following important aspects: the emerging cultural and global demand; the range of the multiplicity of communications channels and media and the growth of cultural and linguistic diversity. The philosophy of multiliteracies was extended by Janes (2009:5) as she explained that there are three key aspects of a multiliteracies concept:

1. pedagogy (a call for educators to become designers of learning);

2. diversity (presenting a broader view of literacy than portrayed by traditional language-based approaches);

3. multimodality (a need for a multiplicity of communication channels).

This study focuses on reading of a graphic novel by students in an ESL classroom by using the multiliteracies approach which was developed by the New London Group (1996). The conceptual framework of the multiliteracies theory illuminates effective pedagogy which describes learning contents that make use of learners' life-world and educational experiences. It considers elements that are involved in producing an effective series of 
lessons such as the variation of technologies, linguistic diversity, culture diversity and individual knowledge process. Based on these factors, Kalantzis \& Cope (2004) suggest that knowledge processes are vital for designing a series of lessons as highlighted in the multiliteracies approach. Suitable topics, subjects and objectives of the lessons would also contribute to the effectiveness of the learning process. The idea of the multiliteracies approach towards a working pedagogy of the knowledge processes can be best represented in the conceptual framework shown in Figure 1:

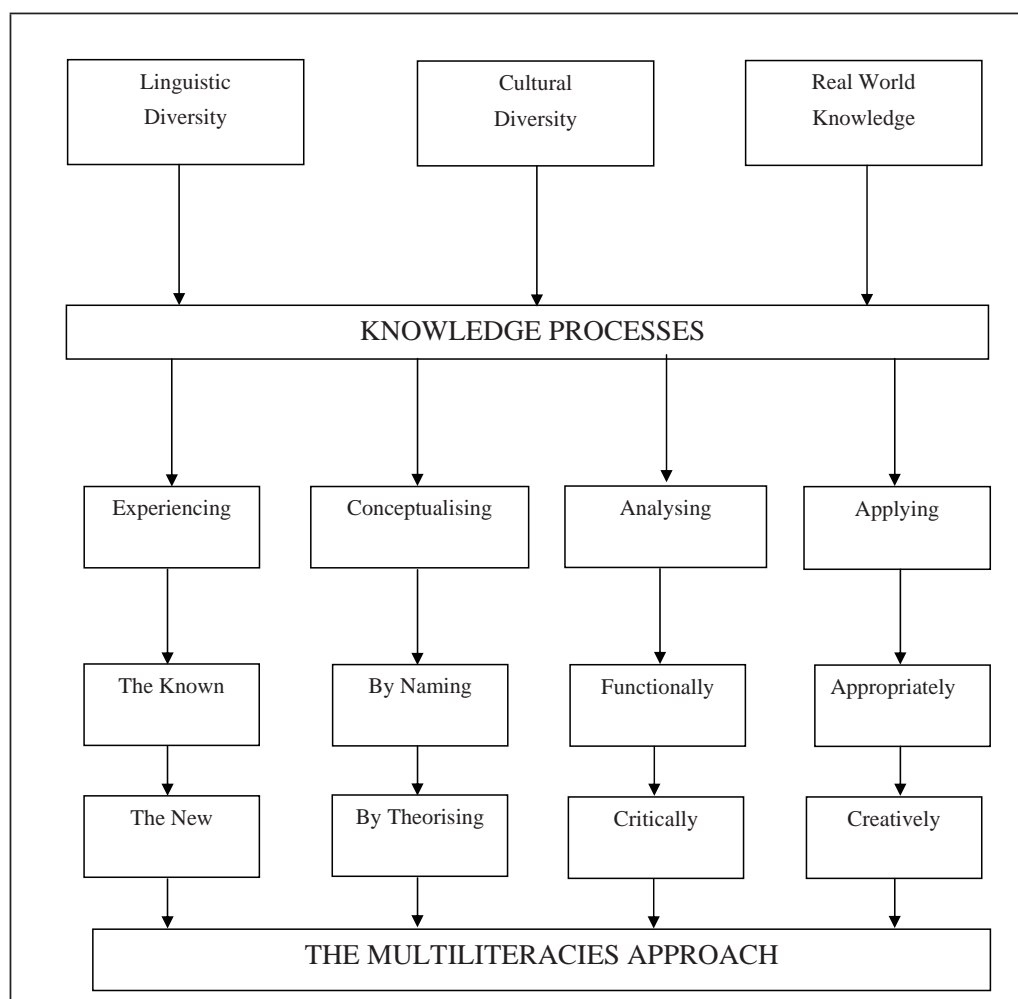

Figure 1. Conceptual Framework of the Study Kalantzis and Cope, 2004:64)

Most importantly, this framework aims to broaden both the teachers' and learners' repertoires of knowledge in meaning making and meets specific learning objectives in different disciplines. It also exposes the learners and teachers to a range of learning and teaching experiences. 
Kalantzis and Cope (2005:72) explained knowledge process as "four fundamental ways of knowing, four processes of acting and meaning". These four knowledge processes are briefly explained as follows:

- $\quad$ Experiencing is a knowledge process which involves learning through immersion in the real world in relation to personal experience, concrete engagement and exposure to evidence, facts and data.

- Conceptualising is a knowledge process involving the development of abstract, generalising concepts and theoretical synthesis of these concepts. It involves moving away from life-world experience along a depth axis that is examining underlying structures, causes and relationships.

- Analysing is a knowledge process involving the examination of constituent and functional elements of a matter. This involves an interpretation of the underlying rationale for a particular piece of knowledge, action, object or represented meaning.

Applying is a knowledge process involving active intervention in the human and natural world, learning by applying experiential, conceptual or critical knowledge by acting in the world on the basis of knowing something of the world and learning something new from the experience of acting.

A recent work in the field of multiliteracies in Malaysia provides some insights on how this pedagogical approach is being used in the classroom. Ganapathy (2007) carried out a study on the use of the multiliteracies approach to promote learner engagement among Form Four students in an ESL classroom. The findings revealed positive implications of the multiliteracies approach on the quality of teaching and learning among the teacher and students at the school. The positive responses by the students and teachers in the study indicate that the multiliteracies approach can be relevant for Malaysian ESL classrooms.

\section{METHODOLOGY}

This study used qualitative methods to collect data. The principal data collection methods in this study were focus group interviews 
and a journal writing activity. Specifically, the study is conducted to fulfill the following objectives:

1. to examine the ESL students' perceptions of reading a graphic novel by using the Multiliteracies Approach

2. to examine the ESL teacher's perceptions of teaching a graphic novel by using the Multiliteracies Approach

The research site is a secondary co-educational school in a semi rural area. The school has a population of 760 students comprising predominantly Malay students (90\%). The participants of this study comprise 24 Form Four students from one intact class and one ESL teacher. In this study, majority of the participants are a group of students who obtained average scores (grade B and C) for the English subject in their PMR (Lower Secondary Assessment) examination the year before and only a small number of students obtained above average scores (grade A). This indicates that they have an intermediate level of English language proficiency. As stated by the ESL teacher in this study, most of the students prefer to speak in Malay once they are outside the classroom as that is their mother tongue and they seldom engage in reading materials in English. The researchers used the purposive sampling strategy (Patton, 2002) to select the participants. Purposive sampling lies in selecting an information-rich case for study so as to "learn a great deal about issues of central importance to the purpose of the inquiry" (Patton, 2002:230). This rationale provided valuable insights and indepth understanding of the study.

In the research process, the purpose and significance of the study were explained and the participants' cooperation was requested. The researcher briefed the participants that they were given the opportunity to participate or to withdraw from the study. The participants were informed that the feedback would be kept confidential and would only be used for academic purposes. Participants were assured of their anonymity throughout the study and they were informed that the findings would only be used for research purposes. The participants were asked to give their honest and sincere answers and they were told that their answers would not be evaluated based on right and wrong answers.

The ESL teacher was exposed to the multiliteracies framework and the graphic novel "The Fruitcake Special", in a training workshop 
conducted by one of the researchers. The researcher clearly explained the learning elements that were incorporated in the reading lessons to the ESL teacher. According to Kalantzis \& Cope (2005: 109), a learning element is an "open and flexible template for planning and documenting pedagogy in the form of a teacher and/or learner oriented text". The design is established through a topic that is coherent with the learning experience documented in the teacher's column on one side and the student learning resource on the other side (Kalantzis \& Cope, 2005). A series of planning activities were considered in the study. The lists of activities and topics that needed to be covered were discussed in the workshop. Following this, six learning activities were developed in collaboration with the ESL teacher (refer to Appendix 2 for a sample lesson plan). After that, the ESL teacher used the graphic novel (together with the multiliteracies approach) in her reading class.

A pilot study was also administered. It was carried out with another intact class which was not involved in the main study to ensure that the research instruments could be understood clearly by the students and the teacher in the study.

The items for the focus group interviews and the journal writing activity were adapted from Ganapathy (2007; 2011). The focus group interviews served the purpose of collecting the respondents' stories, experiences and in-depth details of a topic. Interviews are essential in order to know others' perspectives because they are meaningful and knowable (Patton, 2002). The focus group interviews were conducted in selected discussion rooms in the secondary school. The students were first asked simple questions. Then, they were asked to give explanations and descriptions of their opinions regarding the use of the graphic novel and the multiliteracies approach to the reading lessons. In the transcribed interviews, numbers were given to each participant to ensure anonymity. For example, the code 'FG 1: R1' meant 'Focus Group 1, Respondent 1' and so forth. The data from the focus group interviews were analysed by using thematic analysis proposed by Braun \& Clarke (2006).

Another source of data used was a journal writing activity. The selected ESL teacher was asked to write a journal (on Microsoft Word document) based on the six Learning Elements that had been 
formulated during the training workshop (Appendix 1 and Appendix 2). Each journal entry had to explore the teacher's perceptions of using the graphic novel and the multiliteracies approach to literacy pedagogy in the ESL classroom. The purpose of having journal writing in the study was to gauge the ESL teacher's perceptions of the reasoning process of issues and phenomena that occurred in the study (Lankshear, 2004). Each journal entry was coded for referencing purposes. For example 'JE 1: LE1' meant 'Journal Entry 1, Learning Element 1' and so forth. The data from the six sets of teacher journal entries were subjected to a micro analysis approach using the content analysis method (Crano \& Brewer, 2002).

\title{
FINDINGS
}

\section{a) Students' perceptions of reading a graphic novel by using the Multiliteracies Approach}

\begin{abstract}
The first question in the focus group interviews aimed to seek students' opinions on all the activities that were carried out when they read the graphic novel titled "The Fruitcake Special". Generally, all the students enjoyed the reading activities using the multiliteracies approach. They showed interest and motivation in having such activities in their classroom. The following are some excerpts from the students' interviews:
\end{abstract}

"It was challenging, interesting and enjoyable doing the presentations and my favourite activity was singing presentation. Each group members worked cooperatively and we wrote together our lyrics that was perfectly suit with our song. We chose the latest song from Aqua band group and it was a pop song. It was one of the best moments to perform our song together as a group.

$"(F G 1: R 5)$

"The powerpoint presentations help me to remember the important parts of the story "The Fruitcake Special" such as the plot, characters, moral values and themes. I felt grateful that we had these presentations 
as I always had difficulty in knowing the characters of the story. The mind maps that list the characteristics of the characters with pictures of famous celebrities such as Selena Gomez, Tom Cruise and Nicole Kidman ... surely now this can stick in my brain for longer time. It was so different from the usual classroom!"

(FG1:R6)

"We happy because gotfeedback when we discuss about the presentations. When other group do powerpoint presentations, we can pick out the moral value in the story like working hard to get success. Some of our friends ...they say la they want to be rich chemist like Anna so they want to work hard for SPM next year".

(FG1:R 2)

\begin{abstract}
"I understand the story "Fruitcake Special" better from powerpoint presentations. I also understand the culture and custom in the story. I get idea of matchmaking the couples also happen in foreign country which was same like in Malaysia. This also can see in the story --- Aunt Mimi want to match make Anna with Armstrong".
\end{abstract}

$(F G 2: R 1)$

I like working in a team because we can work together in group in doing presentations.

(FG1:R1)

The next question also required students to express their feelings and perceptions of using different learning methods in reading the graphic novel "The Fruitcake Special". Most of the students stated that they felt enthusiastic about the reading lessons. They viewed the lessons as appealing as the various activities used by their teacher encouraged them to learn English language through the use of technology. The excitement and motivation among the students in learning English through such activities promoted interest among the students to learn collaboratively in the classroom. The following excerpts reflect their feelings about the issue: 
"I think I became more happy...more independent... more interest to learn. I work like a good team because teacher ask us to list in the graphic novel into correct parts of speech such as the nouns, pronouns, adjectives, verbs and prepositions in a scrapbook...usually this very hard for me but for this way of lesson, I found it was an interesting way to learn grammar".

(FG1:R 4)

"I really like teacher use technology in class...this one I sure support. I feel it challenge us. I feel I like it and make me feel I can do more...get better in English.. During the prepare part of these activities, I learn on how to download a short video clip from the YouTube downloader. You know...I really feel so happy when I could share a short video clip on cartoons making lemonade before I present my cake recipes".

$(F G 2: R 1)$

"I think it is good we can use technology to learn English...so much fun! Other type English class before... a bit boring...this one not boring! I like to learn the graphic novel using technology in the multimedia room. The teacher use multimedia presentation to show us step by step baking a fruitcake. It was really interesting".

(FG1:R6)

"The first powerpoint presentation I like already... make us all feel we really like it...I think if learn English like this...sure I want to...can help me confident myself more. Now I think I not so fear to present the scrapbook presentation on the next day".

(FG2: R2)

"I feel motivate to learn and work together with my friends". 
The students were also asked to comment on reading the graphic novel using the multiliteracies approach. Generally, the students were of the opinion that the graphic novel is an interesting medium that attracted their interest to read because it contained interesting visuals. They claimed that the activities involved in reading "The Fruitcake Special" were fun and enjoyable. Most of the students expressed various reasons for reading the graphic novel and the following comments reflect their views:

"The graphic novel is more interesting story and it has nice visuals that reached out to me. I like the caption where Anna wear the lab coat. She looked beautiful and well-dressed as a career woman".

$(F G 2: R 1)$

\begin{abstract}
"Interesting! I really like the graphic novel because I like colourful pictures and this help me want to see picture to read ... usually I don't read English book. It was funny when I see picture of Amos girlfriend, Sabina hit Amos on the face. Then, Amos hit the waiter on the chin. This made me laugh when I reading the story".
\end{abstract}

$(F G 1: R 4)$

"I think it helps me learn new words...really, this help me improve my English! I learn so many new words from the graphic novel such as' peculiarly' and' splatter'. I also learn how people talk with each other especially when Anna as a worker speaks to her boss, Amos".

$(F G 1: R 2)$

"I read this novel...now I think I understand story better! This is good ...I like to see pictures...more fun than see words only....this style I like!"

$(F G 1: R 5)$

The last question dealt with the students' main challenges that they had encountered when they carried out the activities. The students pointed out time factor as one of the constraints. However, the students' determination and strong-will were at the highest level 
during the multiliteracies approach activities;hence, they did not feel very troubled over the issue. Other challenges that were highlighted by the students centered on their competitive spirit in producing the best presentations. They presented some interesting views about the issue in the following excerpts from the focus group interviews:

"I felt nervous! The powerpoint presentations from our classmates were beautiful. They got colourful background, cartoon animations and sounds. It make my group also say....hey, we also want to improve and be more creative so we could compete with them".

$(F G 1: R 4)$

"I really feel shy in front of my friends. Most time...I don't' speak in front of the class. But this time...I say nevermind. .I should try to present the task better so that I would not make my group embarrass with my performance".

$(F G 2: R 4)$

"If you ask me...I really prepare a lot...I do research with my group...we look for cake recipes.... like this type of activity...I love it as I learned different types of cakes from so many website all over internet. I also learn different methods of baking so many types of cakes which I really enjoy. This is the first time I am doing this kind of presentation in English class".

$(F G$ 1:R3)

The overall responses gleaned from the students' focus group interviews showed that they were very enthusiastic and excited to have reading lessons that used a graphic novel and the multiliteracies approach even though they faced a few constraints. The students viewed the challenges in a positive light as they did not feel troubled with the issues and they showed that they were determined to produce the best presentations. 


\title{
b) Teacher's perceptions of teaching a graphic novel by using the Multiliteracies Approach
}

The six journal entries based on each Learning Element revealed that the multiliteracies approach is a very useful method in teaching of how to read a graphic novel. The method was noted as a new platform for presenting the subject matter in the most appealing way. The activities conducted by using the multiliteracies approach were able to attract the students' interest and engaged them in the learning process. These views were stated by the ESL teacher in the following journal entries:

\begin{abstract}
"In my opinion, the graphic novel could promote excitement and motivation in learning English. The students were very interested and were keen on reading the graphic novel as there were a lot of pictures and dialogues which made the story easier to understand. During the lessons, they could clearly describe and point out interesting events of the story in the class without much difficulty such as Amos and the waiter fought because both of them had fallen in love with Anna because of the strange effects from the perfume. I was very pleased to see this positive outcome of using the graphic novel in the classroom".
\end{abstract}

(JE 2: LE2)

\begin{abstract}
"In my opinion, the Multiliteracies Approach could help the students to have better understanding of the graphic novel. This approach helped the students to understand the novel through different techniques to cater for students' various learning needs or styles. For example, the powerpoint presentations especially the diagramming work on the plot of the story had helped the students to understand the development of the story".
\end{abstract}

(JE 3: LE3)

The teacher pointed out that each activity in the Learning Element contributed to the enhancement of learning among her students. These various learning processes were very helpful in terms of 
constructing learners' interpretations and understanding of the text. The integration of ICT in most of the activities also created a positive impact on the teaching of the text. This view was stated by the teacher in her first journal entry:

\begin{abstract}
"The technologies (use of computer to do powerpoint presentations, researching on the internet, experimenting with graphics) are noted as a new platform in introducing the topic so that the students were able to understand the graphic novel better. When I showed the multimedia presentation about methods of baking a fruitcake in the class, they were very excited. This shows that ICT is able to attract students' attention".
\end{abstract}

(JE1:LE1)

In the aspect of collaboration during the activities, the teacher commented positively. The teacher perceived that the activities designed in the Learning Elements initiated cooperation among the students in completing the tasks. This aspect was stated in the following journal entries:

\begin{abstract}
"This activity showed collaboration among the students. They divided the work load equally and most of the students contributed to the completion of the task. I found out that in order for them to categorise the words according to parts of speech, they had assigned the task equally among the group members".
\end{abstract}

(JE 4: LE4)

"The discussion of students' prior knowledge and experience of baking biscuits and cakes during the festivals and celebrations enabled the students to share their ideas with each other".

(JE 1: LE1)

The issue on the level of engagement of the students was discussed frequently in the teacher's journal entries. The teacher stated that her students' level of engagement was high during most of the activities. 
This was reflected in the teacher's journal entries as follows:

\begin{abstract}
"The level of engagement of this activity was high. My students showed their enthusiasm while watching the multimedia presentation. They were also eager to share their experiences in baking cakes during important celebrations in Malaysia like Hari Raya celebration and Chinese New Year celebration".
\end{abstract}

(JE 1: LE1)

\begin{abstract}
"The level of engagement was very high. They had the discussion during the presentation. There were also question and answer sessions. The students were very much interested to get to know about the ingredients used and the methods of baking the cakes which were presented by their friends. Some of the students asked for info of the related websites because they wanted to personally browse the recipes by themselves".
\end{abstract}

(JE 6: LE6)

The high level engagement of the students was evident through their intense participation in the activities. The teacher reported that most of her students were immersed in the activities and gave their full support to make the activities successful. Their enthusiasm was conveyed through their impressive presentations. Generally, the teacher was of the opinion that the multiliteracies approach is a practical method for the implementation of effective teaching in the reading of the graphic novel "The Fruitcake Special".

\title{
DISCUSSION
}

In the study, the students had favourable perceptions of reading a graphic novel by using the multiliteracies approach. Similarly, Hines and Delinger (2011) confirm that the graphic novel improved their students' views towards reading because they felt excited to read. This shows that that a graphic novel has positive characteristics and qualities in supporting reading lessons. By focusing on the 
multiliteracies approach in the reading classroom, most of the students in the study found that the lessons have been tailored according to their interests and motivation. These findings are supported by results of research studies carried out by Ganapathy (2007) and Van Haren (2010), which suggest that the activities designed by the multiliteracies approach can meet students' realworld needs where ICT is the main interest of the students. Despite mainly positive views from the students on activities conducted in the reading classroom using the multiliteracies approach, there were some students who expressed problems and challenges faced by them. However, they perceived the challenges in a positive way as it motivated them to give their best presentation. Van Haren (2010: 269) emphasises on the important role of the teacher to "harness student diversity, scaffold learning, incorporate technology and diverse ways of meaning making, and address student underperformance". Similarly, Swee-Choo, Kung Teck \& Rosma Osman (2012) agreed that teaching and learning in the ESL classroom should focus on facilitating autonomous learning and encouraging the development of critical thinking skills among students. In order to ensure active learning takes place, the teacher needs to take an active role in assisting and motivating the students so that the challenges and problems faced by the students will not obstruct their learning.

In this study, the use of the graphic novel and the multiliteracies approach enriched the students' reading lessons. The ESL teacher reported that the use of the graphic novel and the multiliteracies approach in the reading classroom created an avenue to promote interest in reading English materials and enhance their understanding through the activities conducted in the classroom. The teacher also believed that the students were motivated by the experience of reading the graphic novel and using the multiliteracies approach as it immersed them in the learning process as it was able to create a memorable experience. Such results support findings of another research study conducted by Pandian (2006) in Penang whereby the ESL teacher felt that the multiliteracies approach was most helpful and that the students were very excited as they could learn English in an invigorating way. 


\section{CONCLUSION}

This small-scale case study documented the perceptions of 24 ESL secondary school students and one ESL teacher on the use of the multiliteracies approach in reading a graphic novel and provides opportunities for authentic implementation of learning.

The responses of the teacher and students indicate an overwhelming support for reading a graphic novel using the multiliteracies approach . The respondents indicated a strong belief that the graphic novel and the multiliteracies approach are useful pedagogical tools in promoting an active learning process. This concurs with Van Haren's (2010) finding as she mentioned that the students in her study felt motivated as they as they could present their research using PowerPoint, website, role play, media report, visual representation and video. The learning outcomes were very encouraging as the students were able to produce multiple presentations using ICT skills and technological tools. The study also demonstrates high levels of engagement during the reading lessons and presentations. Despite mostly positive comments, it is worth noting that the ESL teacher and students in this study also identified several problems and challenges that were encountered by them during the reading activities. Nevertheless, they perceived the problems and challenges as a motivation for them to work harder in giving their best in the reading activities.

The integration of the graphic novel and the multiliteracies approach has the potential to create a positive atmosphere in the classroom and school environment as a whole. The Learning Elements advocated in the Learning by Design model (Kalantzis \& Cope, 2010) are useful for preparing and implementing the reading lessons within the Malaysian ESL setting. In this study, the teacher designed the Learning Elements according to the knowledge processes which incorporated multimedia and graphic texts which could enrich the students' understanding of the specific topic (Pandian \& Balraj, 2010). This study has provided valuable insights into traditional English teaching and learning practices and points to the need for appropriate practices that are relevant for 21st century workplaces (Kaur \& Ganapathy, 2013). The findings of the current study also provide useful insights into how the multiliteracies approach and the 
graphic novel can be integrated in the learning context as indicated by many past studies in Malaysia (Ganapathy, 2007; 2011; Pandian, 2006; Pandian \& Balraj , 2005; Ahmad Suhaimi, 2004; Faezal Muniran \& Md Ridzal Md Yusof, 2008; Melor Md Yunus, Hadi Salehi and Mohamed Amin Embi, 2012).

There are several limitations of this study which should be addressed in future research. Firstly, although the study is an attempt to investigate an ESL teacher's and students' perceptions of reading a graphic novel titled "The Fruitcake Special" using the multiliteracies approach, this approach can easily be applied in reading any type of text. More research studies using different types of texts should be conducted in order to examine the usefulness of this approach on a wider scale. The data collected in this study is limited to the perceptions and practices of the selected ESL teacher and students. Inclusion of multiple perspectives from parents and administrators would also contribute to a fuller understanding about the potential of learning using the graphic novel and the multiliteracies approach (Glesne, 2006; cited in Main, 2011). Although the results cannot be generalised, the findings from this case study can serve as a basis for further investigation into understanding the usage of the multiliteracies approach and a graphic novel in an ESL reading classroom.

\section{REFERENCES}

Ahmad Suhaimi, M.S. (2004). Multiliteracies: An exploratory study on the use of the multiliteracies approach in the teaching of English in selected Perak schools (Unpublished master's thesis). Penang: Universiti Sains Malaysia.

Braun, V. \& Clarke, V. (2006). Using thematic analysis in psychology. Qualitative Research in Psychology, 3 (2), 77-101. Callahan, R. B. (2009). Perceptions and Use of Graphic Novels in the Classroom (Unpublished doctoral dissertation). Ohio University.

Crano, W. D., \& Brewer, M. B. (2002). Principles and Methods of Social Research (2nd ed.). Mahwah, NJ: Lawrence Erlbaum Associates.

Faezal Muniran, \& Md. Ridzal Md Yusof. (2008). Using comics and graphic novels in schools and libraries to promote literacies. Paper presented at ICOLIS 2008, Kuala Lumpur, Malaysia. 
Dony, C. (2009). How to use comics in the ESL classroom? Le Journal de Babel g, 27, 1-5.

Ganapathy, M. (2007). Using the Multiliteracies approach to promote learner engagement in an EFL classroom: A case study in a selected school in Penang. (Unpublished master's thesis). Penang: Universiti Sains Malaysia.

Ganapathy,M. (2011). The effects of the multiliteracies approach on the writing performance of EFL students in a Chinese school in Penang: Teacher and student perceptions. (Unpublished doctoral dissertation). Penang: Universiti Sains Malaysia.

Groensteen, T. (2000). Why are comics still in search of cultural legitimization? In A. Magnussen \& H. Christiansen, (Eds.), Comics and culture: Analytical and theoretical approaches to comics (pp. 29-42). Copenhagen, DK: Museum Tusculanum Press.

Heffernan, A. (2009). Rethinking graphic novels in the classroom: Broadening our concepts of literature to benefit readers. Journal of Classroom Research in Literacy, 1, 3-6.

Hines, S. \& Dellinger, K. (2011). The Impact of Reading Graphic Novels on Student Motivation \& Comprehension. Working paper. Appalachian State University.

Hoover, S. (2012). The case for graphic novels. Communications in Information Literacy, 5 (2), 174-186.

Janes, D. (2009). Designing Multiliteracies Curricula for Various Target Learners. Retrieved 20 September 2013 from http:// drofilm1.edublogs.org/artifacts-2/designing-multiliteraciescurricula-for-various-target-learners/

Kalantzis, M., \& Cope, B. (2004). Designs for learning. E-learning, 1(1), 38-93.

Kalantzis, M., \& Cope, B. (2005). Learning by design. Melbourne \& Altona, Vic.: Victorian Schools Innovation Commission in Association with Common Ground Publishing.

Kalantzis, M. \& Cope, B. (2010). The teacher as designer: Pedagogy in the new media age. E-learning and Digital Media, 7(3), 200-222.

Kaur, S., \& Ganapathy, M. (2013). Multiliteracies in Education: Concept and Focus. In S. Kaur, \& Shakila Abdul Manan (Eds), Contemporary Perspectives in English Language Studies: Linguistics and Literature (pp.152-168). Penang: Universiti Sains Malaysia Press.

Lankshear, C. (2004). A handbook for teacher research. New York: McGraw-Hill International. 
Main, K. L. (2011). Mapping multiliteracies onto the pedagogy of $K-12$ teachers (Unpublished doctoral dissertation). Canada: University of Toronto.

Mariyatunnitha Shari. (2008). Male teenagers' need for extensive reading. Paper presented at 1 st International Language Conference (ILC) 2008 Centre for Languages and PreUniversity Academic Development (CELPAD). International Islamic University Malaysia.

Melor Md Yunus, Hadi Salehi, \& Mohamed Amin Embi (2012). Effects of using digital comics to improve ESL writing. Research Journal of Applied Sciences, Engineering and Technology, 4(18), 3462-3469.

Mohd Nazri Latiff Azmi. (2013). National language policy and its impacts on second language reading culture. Journal of International Education and Leadership, 3(1), 1-11

Monnin, K. (2009). Breaking into the superhero boy's club: Teaching Graphic novel literary heroines in secondary English language arts.WILLA XVII: 20-25. EBSCO. Retrieved March 15, 2013 from http: //scholar. lib.vt.edu /ejournals /WILLA/ fall09 /monnin. html

New London Group. (1996). A pedagogy of multiliteracies: designing social futures. Harvard Educational Review, 66(1), 60-92.

New London Group. (2000). A pedagogy of multiliteracies: Designing social futures. In B.Cope \& M. Kalantzis (Eds.), Multiliteracies: Literacy Learning and the Design of Social Futures (pp. 182-202), Melbourne, Macmillan.

Noorliza Abu Bakar. (2006). The impact of reading preferences on high achievers'academic achievements of Sekolah Kebangsaan Tok Dir, Kuala Terengganu (Unpublished master's thesis). Terengganu: UiTM Terengganu.

Pandian, A. (2000), A study on readership behavior among multiethnic, multi-lingual Malaysian students, paper presented at the 7th International Literacy and Education Research Network (LERN) Conference on Learning. RMIT University, Melbourne.

Pandian, A. (2006). What works in the classroom? Promoting literacy practices in English 3L. The Southeast Asian Journal of English Language Studies, 11, 15-39.

Pandian, A., \& Balraj, S. (2005). Approaching Learning by design as an agenda for Malaysian schools. In M. Kalantzis, B.Cope 
$\&$ the Learning by Design Project Group. Learning by Design (pp. 285-313). Melbourne \& Altona, Vic.: Victorian Schools Innovation Commission in Association with Common Ground Publishing.

Pandian, A. \& Balraj, S. (2010). Driving the agenda of learning by design in Science literacy in Malaysia .E-Learning and Digital Media, 3(7), 301-306.

Patton, M.Q. (2002).Qualitative research \& evaluation methods. California. Thousand Oak: Sage Publication.

Ruppel, K.K. (2006). Getting graphic: Connecting with students using graphic novels. Retrieved 15 March 2013 from http://www. mcelmeel.com /curriculum /yalit/ruppe 1_ graphicnovels.pdf Schwarz, G.E. (2002). Graphic novels for multiple literacies. Journal of Adolescent \& Adult Literacy, 46(3), 262-265.

Schwarz, G.E. (2006). Expanding literacies through graphic novels. Retrieved 1 April 2013 from: http://www.ncte.org/Library/ files/Free/recruitment/EJ0956Expanding.pdf.

Smetana, L., Odelson, D., Burns, H., \& Grisham, D.L. (2009). Using graphic novels in the high school classroom: Engaging deaf students with a new genre. Journal of Adolescent and Adult Literacy, 53(3), 228-240

Swee-Choo, P., Kung Teck, W., \& Rosma Osman (2012). StudentTeachers' approaches to learning, academic performance and teaching efficacy. Malaysian Journal of Learning Instruction, 9, 31-45.

Tan, Y. L. \& Yudi Samyudia. (2009). Learning Styles versus Teaching Styles: How to match them? Paper presented at Teaching \& Learning Open Forum 2009.

Templer, B. (2009). Graphic novels in the ESL classroom: Humanising Language Teaching, 11 (3). Retrieved 20 May 2013 from http://www.hltmag.co.uk/jun09/mart03.htm

Thompson, T. (2008). Adventures in graphica: Using comics and graphic novels to teach comprehension, 2-6. Portland, ME: Stenhouse.

Van Haren, R. (2010). Engaging learner diversity through learning by design. E-Learning and Digital Media, 7(3), 258-271.

Williams, R. M. C. (2008). Image, text, and story: Comics and graphic novels in the classroom. Art Education, 61 (6), 13-19.

Yang, G. (2008).Graphic novels in the classroom. Language Arts, 3(85), 185-192. 


\section{APPENDICES}

\section{Appendix 1}

\section{Learning Elements}

\begin{tabular}{|c|c|}
\hline & \\
\hline & \\
\hline & \\
\hline & \\
\hline \multicolumn{2}{|c|}{$\begin{array}{l}\text { Knowledge Objectives: } \\
\text { To experience } \\
\text { As a result of completing this Learning Element, students will be able } \\
\text { to: } \\
\text { - Experience reading the graphic novel“" The Fruitcake Special” } \\
\text { - Experience creating Powerpoint slides, Scrapbook, Graphic and } \\
\text { Audio presentation }\end{array}$} \\
\hline \multicolumn{2}{|c|}{$\begin{array}{l}\text { To conceptualise } \\
\text { As a result of completing this Learning Element, students will be able } \\
\text { to: } \\
\text { - Put the concepts together to describe the characteristic features of } \\
\text { - Include and design text features, sound features and visual features } \\
\text { in Powerpoint, Scrapbook, Graphic and Audio presentation }\end{array}$} \\
\hline \multicolumn{2}{|c|}{$\begin{array}{l}\text { To analyse } \\
\text { As a result of completing this Learning Element, students will be able } \\
\text { to: } \\
\text { - Examine the ideas and viewpoints that were gained from reading } \\
\text { the graphic novel "The Fruitcake Special" and the presentations } \\
\text { - Critically analyse materials that are downloaded from the Internet } \\
\text { for presentations }\end{array}$} \\
\hline \multicolumn{2}{|c|}{$\begin{array}{l}\text { To apply } \\
\text { As a result of completing this Learning Element, students will be able } \\
\text { to: } \\
\text { - Design scrapbook } \\
\text { - Produce a cookbook on cakes' recipes } \\
\text { - Create a song } \\
\text { - Create a powerpoint presentation }\end{array}$} \\
\hline
\end{tabular}




\section{Appendix 2}

Content page-list of activities and Topics covered (A Sample Lesson plan)

\begin{tabular}{|l|l|}
\hline Teacher Resource & Contents \\
\hline Learning Objectives & \\
\hline Learning Activity \\
- Get the students to look at \\
relevant information on the \\
elements of the graphic novel \\
" The Fruitcake Special" as \\
follows: \\
- Setting \\
- Story Plot \\
- Characters \\
- Themes \\
- Moral Values
\end{tabular}

- Discussion on input that students are supposed to present based on the elements given.

- Guidelines:

- Setting-Physical setting

- Story plot-exposition, rising action, climax, falling action, resolution

- Characters-major and minor characters -characteristics and qualities of the characters

- Themes- 3 major themes in the story

- Moral values- 3 important moral values in the story

- Guidelines are given on creation of Powerpoint.

Guidelines:

- Powerpoint slides should not exceed 10 slides

- Include pictures and graphic elements 
- The content should be brief and accurate

- Students present their Powerpoint presentations in class based on the elements as follows:

- $\quad$ Setting (Group 1)

- $\quad$ Story Plot (Group 2)

- Characters( Group 3)

- Themes (Group 4)

- Moral Values (Group 5)

- In this part, students can utilise various elements to help them to focus more efficiently on the text and they would have a better chance of understanding the text successfully.
- You will present relevant information in class using a Powerpoint presentation.

- Setting (Group 1)

- Story Plot (Group 2)

- Characters( Group 3)

- Themes (Group 4)

- Moral Values (Group 5)

- You will utilise various elements of the story to help you focus on the text which would assist you to understand the text successfully. 